\title{
Substitution of Arginine-839 by Cysteine or Histidine in the Androgen Receptor Causes Different Receptor Phenotypes in Cultured Cells and Coordinate Degrees of Clinical Androgen Resistance
}

\author{
Lenore K. Beitel, * Parsa Kazemi-Esfarjani, *‡ Morris Kaufman, *1 Rose Lumbroso, * Angelo M. DiGeorge, * * \\ Donald W. Killinger, \# Mark A. Trifiro, ${ }^{* \$}$ and Leonard Pinsky*\$\$ $\| \uparrow$ \\ ${ }^{*}$ Lady Davis Institute for Medical Research, Sir Mortimer B. Davis-Jewish General Hospital, Departments of ${ }^{\ddagger}$ Biology, ${ }^{8}$ Medicine, and \\ "Pediatrics, 'Centre for Human Genetics, McGill University, Montreal, Quebec H3T 1E2, Canada; **St. Christopher's Hospital for \\ Children, Philadelphia, Pennsylvania 19134; and ${ }^{\ddagger \ddagger}$ St. Joseph’s Hospital, London, Ontario N6A 4V2, Canada
}

\begin{abstract}
We aim to correlate point mutations in the androgen receptor gene with receptor phenotypes and with clinical phenotypes of androgen resistance. In two families, the external genitalia were predominantly female at birth, and sex-ofrearing has been female. Their androgen receptor mutation changed arginine-839 to histidine. In a third family, the external genitalia were predominantly male at birth, and sex-of-rearing has been male: their codon 839 has mutated to cysteine. In genital skin fibroblasts, both mutant receptors have a normal androgen-binding capacity, but they differ in selected indices of decreased affinity for $\mathbf{5} \alpha$-dihydrotestosterone or two synthetic androgens. In transiently cotransfected androgen-treated COS-1 cells, both mutant receptors transactivate a reporter gene subnormally. The His-839 mutant is less active than its partner, primarily because its androgen-binding activity is more unstable during prolonged exposure to androgen. Adoption of a nonbinding state explains a part of this instability. In four other steroid receptors, another dibasic amino acid, lysine, occupies the position of arginine-839 in the androgen receptor. Androgen receptors with histidine or cysteine at position 839 are distinctively dysfunctional and appear to cause different clinical degrees of androgen resistance. (J. Clin. Invest. 1994. 94:546-554.) Key words: androgen • receptor • mutation • steroid $\cdot$ resistance
\end{abstract}

\section{Introduction}

The androgen receptor $(\mathrm{AR})^{1}$ protein is an androgen-sensitive transcription factor. Androgen binding enables its DNA-binding

Address correspondence to Dr. L. Pinsky, Lady Davis Institute, 3755 Cote Ste. Catherine Road, Montreal, Quebec H3T 1E2, Canada.

Received for publication 10 November 1993 and in revised form 22 March 1994.

1. Abbreviations used in this paper: $\mathrm{AI}$, androgen insensitivity; AR, androgen receptor; DHT, [1,2,4,5,6,7- $\left.{ }^{3} \mathrm{H}\right] 5 \alpha$-dihydrotestosterone; GSF, genital skin fibroblasts; h, human; $k$, nonequilibrium rate constant of dissociation; $K_{\mathrm{d}}$, (apparent) equilibrium dissociation constant; MB, $\left[17 \alpha\right.$-methyl- $\left.{ }^{3} \mathrm{H}\right]$ mibolerone; MMTV.GH, mouse mammary tumor virus.growth hormone; MT, $\left[17 \alpha\right.$-methyl- $\left.{ }^{3} \mathrm{H}\right]$ methyltrienolone; $\mathrm{PCMV} . \beta$ gal, cytomegalovirus promoter. $\beta$-galactosidase reporter gene construct; $\mathrm{T}$, testosterone.

J. Clin. Invest.

(c) The American Society for Clinical Investigation, Inc. 0021-9738/94/08/0546/09 \$2.00

Volume 94, August 1994, 546-554 domain to recognize particular regulatory sequences of DNA (androgen-response elements) and thereby to increase or decrease the expression of certain target genes. In 1974 (1) several laboratories $(2,3)$ began to characterize the androgen-binding activities in the genital skin fibroblasts (GSF) of 46,XY humans with various clinical expressions of androgen resistance (insensitivity), on the presumption that they had mutant ARs. More recently, the cloning of the AR cDNA (4-7) and the application of derivative molecular techniques have permitted us (8-14) and others (15-27) to try to correlate specific germline lesions in the androgen-binding region of $\mathrm{X}$-linked $A R$ gene with various dysfunctional behaviors of the $A R$ and with their clinical consequences for the affected subjects. The ultimate aim of such correlative studies is to elucidate the stereochemistry that imparts androgen-binding specificity to an AR and the contribution of an androgenic ligand to the transcriptional regulatory attributes of an A-R complex. In this paper, we describe three families that have alternative, single-nucleotide, missense mutations at the Arg- $839^{2}$ codon in exon 7 of the androgen-binding domain of the $A R$ gene (Fig. 1).

\section{Methods}

Subjects and their families. 4308, the index subject in a black-American family, was described previously (28). She was born with a single perineal urogenital orifice flanked by labioscrotal folds. With the aid of corrective surgery, she and an affected maternal aunt were reared as females. The properties of the specific androgen-binding activity in 4308's GSF (28) are recalled, as appropriate, below.

A.E.L. and K.E.L. are maternal half-sisters in a second black-American family, historically unrelated to the one above. A.E.L. was brought to the St. Christopher's Hospital for Children at age 2 wk because of a right groin mass. There was posterior labial fusion and questionable clitoromegly. The karyotype was $46, \mathrm{XY}$. At age 4 mo, vaginography revealed a short, blind vagina, and extirpative surgery revealed histologically normal testes, epididymes, and proximal vasa deferentia. K.E.L. was born 6 yr later with a $1.5-\mathrm{cm}$ clitoris, posterior labial fusion, and masses in the right labium majus and left groin. Vaginography revealed a short, blind vagina. The karyotype was $46, X Y$. At age $8 \mathrm{mo}$, basal serum testosterone was $197 \mathrm{ng} / \mathrm{dl}$; after 4,000 IU of human chorionic gonadotropin daily for $3 \mathrm{~d}$, it rose to $980 \mathrm{ng} / \mathrm{dl}$. Bilateral orchiectomy revealed normal testicular histology. The abnormalities of the specific androgen-binding activity in the GSF of these two half-sister subjects are presented here for the first time.

335002 and 333203 are brothers in a white-Canadian family. 335002 was born with cryptorchidism and penile hypospadias; each required

2. Number according to reference 4: the same codon is numbered 840 in reference 5 and 838 in reference 7. 


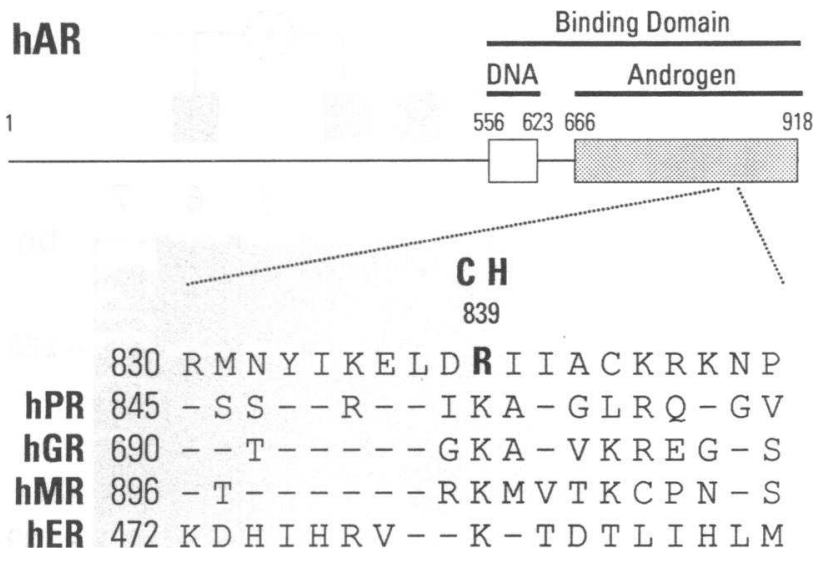

Figure 1. (Top) A linear version of the DNA- and androgen-binding domains of the human AR, indicating their terminal amino acids. (Bottom) An expanded portion of exon 7 indicating the location of residue 839 and its mutant amino acid substitutions. For comparison, the homologous residues are given for the human forms of the receptors for progesterone $(P)$, glucocoticoid $(G)$, mineralocorticoid $(M)$, and estrogen (E). The single letter code for amino acids is: A, alanine; $C$, cysteine; D, aspartic acid; E, glutamic acid; F, phenylalanine; G, glycine; $\mathrm{H}$, histidine; I, isoleucine; $\mathrm{K}$, lysine; $\mathrm{L}$, leucine; $\mathrm{M}$, methionine; $\mathrm{N}$, asparagine; $\mathrm{P}$, proline; $\mathrm{Q}$, glutamine; $\mathrm{R}$, arginine; $\mathrm{S}$, serine; $\mathrm{T}$, threonine; $\mathrm{V}$, valine; $\mathrm{W}$, tryptophan; and $\mathrm{Y}$, tyrosine.

staged surgical correction. Bilateral gynecomastia appeared at $12 \mathrm{yr}$ and required reduction mammoplasty. Pubic and axillary hair appeared at age 14. At $22 \mathrm{yr}$, he had no facial or chest hair; pubic hair was Tanner stage 3. The right testis was $25 \mathrm{ml}$; the left was $10 \mathrm{ml}$. He is potent. Between 20 and $23 \mathrm{yr}$ of age, repeated serum total testosterone (T) determinations varied from 72 to $180 \mathrm{nM}$ (normal: 10-35) while his non-sex hormone-binding globulin-bound (free $\mathrm{T}$ ) levels varied from 8.3 to $31 \mathrm{nM}$ (normal: $3-13$ ). On these occasions, his free $\mathrm{T}$ varied from 12 to $17 \%$ of the total serum $\mathrm{T}$. In normal males, the fraction of total $\mathrm{T}$ that is not bound to sex hormone-binding globulin is $\sim 30 \%$. The values for luteinizing hormone ( $\mathrm{LH})$ varied from 16 to $23 \mathrm{U} /$ liter (normal: 2-15), and those for follicle-stimulating hormone (FSH) have been 15 on two occasions (normal: 4-18). After $3 \mathrm{~d}$ of abstinence, a $0.5-\mathrm{ml}$ sample of semen contained 11.8 million sperm $/ \mathrm{ml} ; 10 \%$ had normal motility, but $90 \%$ had normal morphology. 333203 was born $3.5 \mathrm{yr}$ later with a nonhypospadic micropenis and bilateral cryptorchidism that needed several orchidopexy procedures. Bilateral gynecomastia required mammoplasty at age 14 . At $19 \mathrm{yr}$ he had no facial or chest hair; axillary hair was plentiful; pubic hair was Tanner stage 4 . The penis was only $3 \mathrm{~cm}$ long. The testes were $8 \mathrm{ml}$ bilaterally. At $20 \mathrm{yr}$, when his total serum $\mathrm{T}$ was $74 \mathrm{nM}$, the free was $12 \mathrm{nM}, 17 \%$ of the total; the LH level was $21 \mathrm{U} /$ liter (normal: 5-25), and the FSH was 29 U/liter (normal: 4-18). The affected brothers have three affected maternal first cousins once removed, two of whom are siblings. Two were born with penile chordee; one had micropenis with hypospadias at the penile base. All three had a nonbifid scrotum and have been reared as males with supportive surgery.

Androgen-binding activity in cultured cells. For GSF, specific androgen-binding activity, maximum androgen-binding capacity, the apparent equilibrium dissociation constant $\left(K_{d}\right)$, the rate constant of dissociation $(k)$, and theromstability of various A-R complexes or of the free AR were determined on monolayer cultures as described previously (29). The same methods were used for COS-1 cells except that they were washed and lysed in $0.5 \mathrm{~N} \mathrm{NaOH}$ directly in the culture dishes. The androgens used were: $\left[17 \alpha\right.$-methyl- $\left.{ }^{3} \mathrm{H}\right]$ mibolerone $(\mathrm{MB} ; 7 \alpha, 17 \alpha$-dimethyl-19-nortestosterone; $80 \mathrm{Ci} / \mathrm{mmol}) ;\left[1,2,4,5,6,7-{ }^{3} \mathrm{H}\right] 5 \alpha$-dihydrotestosterone (DHT; $120 \mathrm{Ci} / \mathrm{mmol})$; and $\left[17 \alpha\right.$-methyl- $\left.{ }^{3} \mathrm{H}\right]$ methyltrienolone (MT; $17 \beta$-hydroxyl-17 $\alpha$-methyl-4,9,11-estriene-3-one; 87 $\mathrm{Ci} / \mathrm{mmol}$ ). The synthetic androgens are nonmetabolizable.

$P C R$ amplification and direct DNA sequencing of AR genomic exons. These were modified (30) from methods described in reference 12.

Construction of cDNA expression vectors with $R 839 H$ or $R 839 C$. The germline sequence alterations identified in the DNA of representative affected subjects were reproduced using a modification of Higuchi's (31) site-directed PCR mutagenesis method. Four separate primary PCR reactions were performed using $2 \mu \mathrm{g}$ of the human (h) AR cDNA expression vector $\mathrm{pSVhAR.BHEX}{ }^{3}$ as template and 50 pmol each of the following primers (mutated bases are underlined and bold faced): 1a. inside, AEL-A (5'-CAAGGAACTCGATCATATCATTGC-3')

b. outside, SVEco (5'-GGAATTCCTCACTGGGTGTGGAAATAGA-3')

2a. inside, AEL-B (5'-GCATGCAATGATATGATCGAG-3')

b. outside, Primer B ( $5^{\prime}$-TCACACATTGAAGGCTATGA-3')

3a. inside, 335002-A (5'-CAAGGAACTCGATTGTATCATTGC-3')

b. outside, Primer P3' (5'-GCTGCCTATCAGAAGGTTGGTG-3')

4a. inside, 335002-B ( 5'-GCAATGATACAAATCGAGTTCCTTG-3')

b. outside, Primer B (see $2 \mathrm{~b}$ above).

The primary fragments were amplified for 25 cycles by Pfu DNA polymerase (Stratagene, La Jolla, CA) with the following parameters: denaturation at $95^{\circ} \mathrm{C}$ for $1 \mathrm{~min}$, annealing at $55^{\circ} \mathrm{C}$ for $75 \mathrm{~s}$, and extension at $75^{\circ} \mathrm{C}$ for $90 \mathrm{~s}$. The fragments from the four primary PCR reactions were gel-purified and resuspended in $20 \mu \mathrm{l} \mathrm{H}_{2} \mathrm{O}$, and 1-2 $\mu \mathrm{l}$ of the latter was used for the secondary PCR in the following combination

3. pSVhAR.BHEX is a version of $\mathrm{pSVhAR}_{\mathrm{o}}$ (32) that we have made more useful by making three of its restriction sites unique and by introducing a fourth site at codons 676-677 in the AR, numbered according to reference 4 .
TGCTCCTTCGTGGGCATGCTTCCCCTCCCCATTCTGTCTTCATCCCACATCAG TT CCA GTG primer $\longrightarrow$ le Pro Val

GAT GGG CTG AAA AAT CAA AAA TTC TTT GAT GAA CTT CGA ATG AAC TAC Asp Gly Leu Lys Asn Gin Lys Phe Phe Asp Glu Leu Arg Met Asn Tyr

Cys TA Mis
Ile Lys Glu Leu Asp $\underbrace{\mathbf{8 3 9}}_{\text {Pvul }}$

TCC TGC TCA AGA CGC TTC TAC CAG CTC ACC AAG CTC CTG GAC TCC GTG Ser Cys Ser Arg Arg Phe Tyr Gln Leu Thr Lys Leu Leu Asp Ser Val

CAG CCT GTAAGCAAACGATGGAGGGTGCTTTATCAGGGAGACAGCCTGATAGAGCCA

Gln Pro
$\Longleftarrow$ primer $\mathrm{B}$
Figure 2. The nucleotide, amino acid, and flanking intronic sequences of exon 7 in the $A R$ gene. The PCR primers are underlined. Arg-839, the cytosine $(C) \rightarrow$ thymine $(T)$ transition leading to Cys-839, and the guanine $(G) \rightarrow$ adenine (A) transition leading to His- 839 are in bold. The PvuI recognition sequence that is altered by each mutation is bracketed. 
reactions: for A.E.L. (R839H) fragments from reactions 1 and 2; for 335002 (R839C) fragments from reactions 3 and 4 . The secondary PCR reactions contained $0.5 \mathrm{pmol}$ of each of the respective internal primers and 50 pmol of each of the outside primers: for 335002, P3' and Primer B; for A.E.L., SVEco and Primer B. Except for the greater number of cycles ( 35 cycles), the cycle parameters were the same as the primary PCR reactions. The fragments from the four secondary PCR reactions were gel-purified. R839C (335002) fragments were double-digested with restriction enzymes EcoRI and BamHI, and R839H (A.E.L.) fragments were digested with EcoRI. The digested fragments were ligated into pSVhAR.BHEX ${ }^{3}$ (R839C) or pSVhAR $_{\mathrm{o}}(\mathrm{R} 839 \mathrm{H})$, each deleted for the corresponding restriction fragments. XL1 Blue competent bacteria were transformed with the ligation products, and the colonies were screened by PvuI restriction enzyme digestion (both mutations abolish a PvuI site in the hAR cDNA). The appropriate clones were grown in $500 \mathrm{ml}$ of liquid cultures, and the plasmid vectors were purified by QIAGEN columns (QIAGEN Inc., Chatsworth, CA). The inserted fragments were sequenced by the dideoxy method to confirm exclusivity of the site-directed nucleotide substitutions.

Assessment of transactivational efficiency of mutant ARs with R839H or $R 839 \mathrm{C}$. The construction of the mouse mammary tumor virus.human growth hormone (MMTV.hGH) reporter plasmid and its cotransfection with the pCMV. $\beta$-gal vector to assess transfection efficiency have been reported $(12,13)$. To achieve consistent relative transactivational activities among replicate experiments, the prior transfection protocol (13) was modified as follows: we electroporated confluent COS-1 cells at $350 \mathrm{~V} / 960 \mu \mathrm{F}(\sim 20 \mathrm{~ms})$ in the presence of $1 \mu \mathrm{g}$ normal or mutant pSVhAR and $20 \mu \mathrm{g}$ pMMTV.GH, and $6 \mathrm{~h}$ later we exposed the cells to various concentrations of mibolerone for an additional $72 \mathrm{~h}$.

Western analysis of the AR in transfected COS-1 cells. Confluent monolayers $(\sim 1$ million cells $)$ in 30 -mm multiwell petri dishes were washed twice with $20 \mathrm{mM}$ Tris/HCL (pH 7.4) containing $0.15 \mathrm{M} \mathrm{NaCl}$, and the scraped cells from duplicate dishes were combined in $1 \mathrm{ml}$ of the same buffer. After microfuging, the cells were resuspended in 160 $\mu \mathrm{l}$ of $0.25 \mathrm{M}$ Tris $/ \mathrm{HCl}(\mathrm{pH} 7.8$ ) containing $3.5 \%$ ( vol/vol) aprotinin (Sigma Immunochemicals, St. Louis, MO), lysed by three freeze-thaw cycles, and microfuged $\left(12,000 \mathrm{~g}, 5 \mathrm{~min}, 4^{\circ} \mathrm{C}\right) .50 \mu \mathrm{l}$ of the supernatant was used for protein assay (33), and $100 \mu \mathrm{g}$ of supernatant protein from each sample was subjected to SDS-PAGE and Western transfer by electroblotting according to standard methods (34). The nitrocellulose filters were blocked by immersion in TBS $(20 \mathrm{mM}$ Tris/ $\mathrm{HCl}[\mathrm{pH}$ 7.4 ] and $500 \mathrm{mM} \mathrm{NaCl}$ ) with $0.5 \%$ Tween 20 for $1 \mathrm{~h}$ at room temperature and incubated overnight at $4^{\circ} \mathrm{C}$ with a monoclonal antibody (F39.4.1) to a peptide (Sf61) corresponding to amino acids 301-320 in the $\mathrm{NH}_{2}$-terminal portion of the hAR (35). The antibody was diluted $1: 10,000$ in TBS with $0.05 \%$ Tween 20 . After three washes in TBS with $0.5 \%$ Tween 20 , the filters were incubated with a 1:5,000 dilution of horseradish peroxidase goat anti-mouse IgG for $1 \mathrm{~h}$ at room temperature. After five more washes in TBS with $0.5 \%$ Tween 20 , the blot was developed using the ECL chemiluminescence detection system (Amersham Corp., Arlington Heights, IL). Using the LKB Ultroscan XI densitometer and the Pharmacia Gel Scan XL program (Pharmacia LKB Biotechnology Inc., Piscataway, NJ), we validated the chemiluminescence method by demonstrating linearity with $10-300 \mathrm{fmol}$ of androgenbinding activity in the standard Western blotting procedure and by exposing film to the Luminol reaction for various times (30 s-20 min) to define a window during which relative band intensity remained constant densitometrically.

\section{Results}

Identification and restriction-site analysis of the mutations. By PCR amplification and direct sequencing of exons 1-8, we found the guanine to adenine transition responsible for Arg839His first in the GSF of subject 4308 and then in those of the half-sisters A.E.L./K.E.L. (Fig. 2). In the same way, we

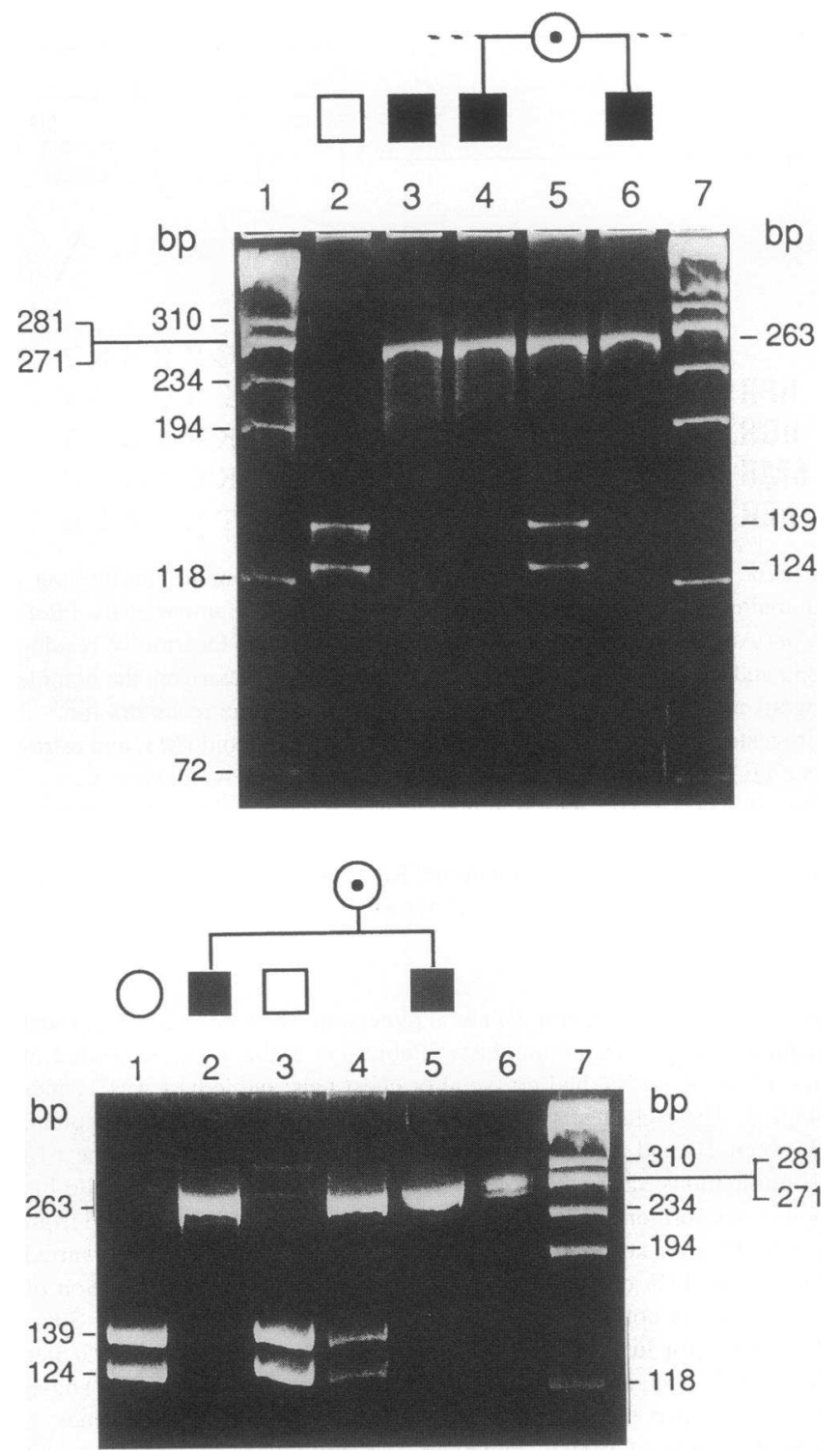

Figure 3. Ethidium bromide-stained, 8\% PAGE analysis of PvuI-treated PCR-amplified normal and mutant exon 7. (Top) Lanes 1 and 7, size standards generated by HaellI digestion of $\phi X 174$ RF. Lane 2, a normal person; lane 3, subject 4308; lanes 4 and 6 , the half-sister subjects, A.E.L. and K.E.L., respectively; lane 5, their mother. When exon 7 of the hAR is amplified between the intronic primers indicated in Fig. 2 it is within a 263-bp product. A normal allele is cleaved by PvuI into 139- and 124-bp fragments. The mutant allele resists cleavage. Hence, the heterozygous mother has three bands. (Bottom) Lanes 1 and 3, unrelated normal persons; lanes 2 and 5, the brothers 335002/333203; lane 4, their mother; lane 6, same as lane 5 but not exposed to PvuI; lane 7 , size standards as above.

later found the cysteine to thymine transition responsible for Arg839Cys in the brothers $335002 / 333203$ (Fig. 2). The ablation of a PvuI site by either substitution allowed us to prove maternal heterozygosity for the half-sisters A.E.L./K.E.L. (Fig. 3, top) and for the brothers 335002/333203 (Fig. 3, bottom). The families of 4308 and A.E.L./K.E.L. are historically unrelated. They also differ in the highly polymorphic length (36) of the poly-glutamine tract in exon 1 of the $A R$ gene: 4308 has 


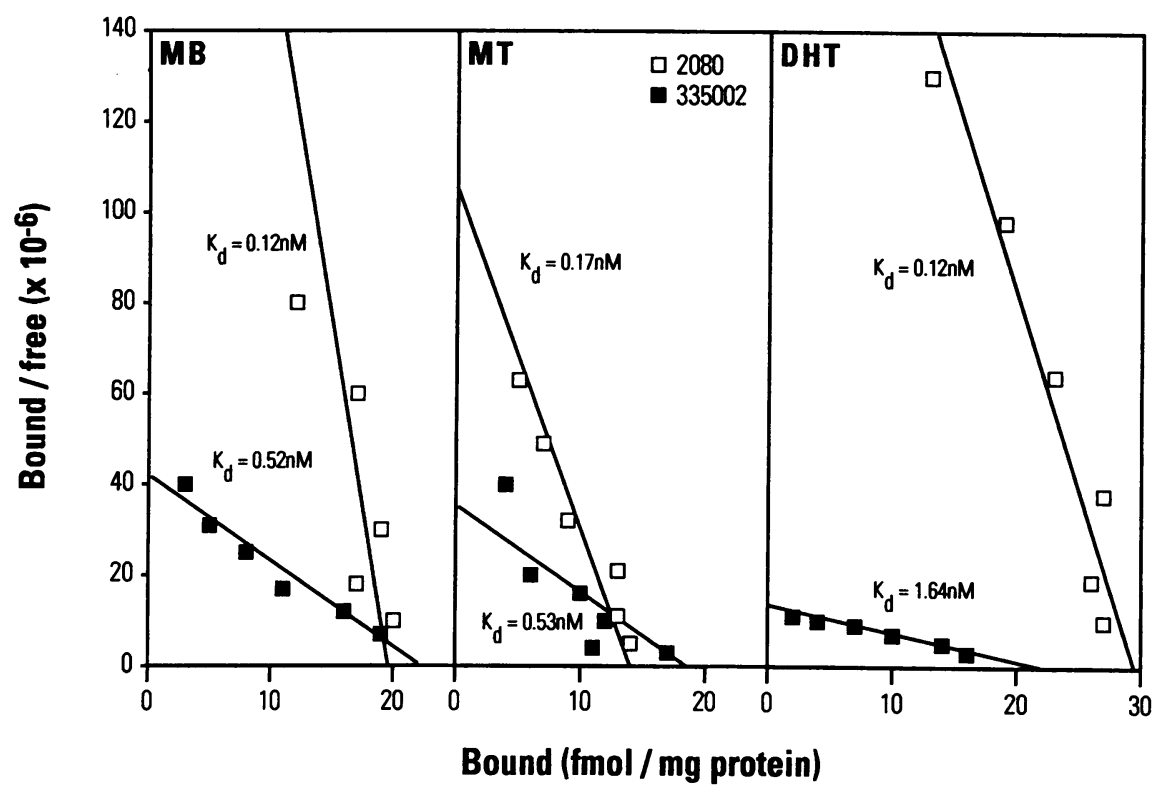

Figure 4. Scatchard plots representing saturation analysis performed on the specific MB-, MT-, and DHT-binding activities in whole GSF. 2080, normal; 335002, mutant AR Arg839Cys. The $K_{\mathrm{d}}$ was computed from the slope of a line; maximum androgen-binding capacity was estimated by its intercept on the horizontal axis.
19 repeats, A.E.L./K.E.L. have 18, their mother has ones of 18 and 20; and 335002 has 20.

Androgen-binding activity in GSF. We first determined various androgen-binding parameters of the mutant AR in the GSF of the half-sisters A.E.L./K.E.L. and the brothers 335002/ 333203. Fig. 4 shows that 335002's AR has modestly increased $K_{\mathrm{d}}$ values for MB, MT, and DHT that are comparable with those published previously (28) for $4308(0.57,2.2$, and 1.0 $\mathrm{nM}$, respectively; normal $<0.3 \mathrm{nM}$ ) and to those of A.E.L./ K.E.L. (0.35, 1.0 , and $0.56 \mathrm{nM}$, respectively).

The MB - and MT-R complexes preformed in the GSF of 333203 or A.E.L. at $37^{\circ} \mathrm{C}$ were much more thermolabile than normal when the cells were postincubated at $41^{\circ} \mathrm{C}$ with 100 $\mu \mathrm{M}$ cycloheximide in the presence of $3 \mathrm{nM}$ of the appropriate $\left[{ }^{3} \mathrm{H}\right]$ androgen (Fig. 5). Furthermore, the Arg839His MB-receptor complexes in A.E.L. were more thermolabile than the Arg839Cys ones in 333203. However, when the GSF of subject 333203 or A.E.L. were incubated at $37^{\circ} \mathrm{C}$ in serum-free medium overnight and then exposed to $100 \mu \mathrm{M}$ cycloheximide at $41^{\circ} \mathrm{C}$, they lost their androgen-binding activity during the next $2 \mathrm{~h}$ at the same rate as control GSF ( $t=1.5 \mathrm{~h}$; data not shown). These disparate responses of A.E.L.'s GSF to thermal stress closely resembled those in 4308's GSF under slightly different conditions (28).

Table I shows the rates at which various $\left[{ }^{3} \mathrm{H}\right] \mathrm{A}-\mathrm{R}$ complexes dissociated in GSF chased by a great excess of the corresponding radioinert androgen at specific temperatures. A.E.L.'s DHT-R complexes dissociated moderately faster than normal not only at $37^{\circ} \mathrm{C}$, as suggested by those of 4308 , but also at 40 and $42^{\circ} \mathrm{C}$. In contrast, $335002 / 333203$ had normal DHT $k$ values ("off-rates") at 37 and $42^{\circ} \mathrm{C}$. Likewise, these brothers had a normal mean MT $k$ value at $37^{\circ} \mathrm{C}$, whereas the corresponding value for A.E.L. and 4308 was suspiciously high. Notably, A.E.L., 4308, and the brothers 333203/335002 all had normal MB $k$ values at $37^{\circ} \mathrm{C}$; yet, all three tested had clearly increased MB $k$ values at 40 and $/$ or $42^{\circ} \mathrm{C}$. We have reported such patterns of ligand-specific, temperature-restricted departures from normal $k$ values in the GSF of other subjects with partial androgen resistance (37).

Androgen-binding and transactivational activity of trans-

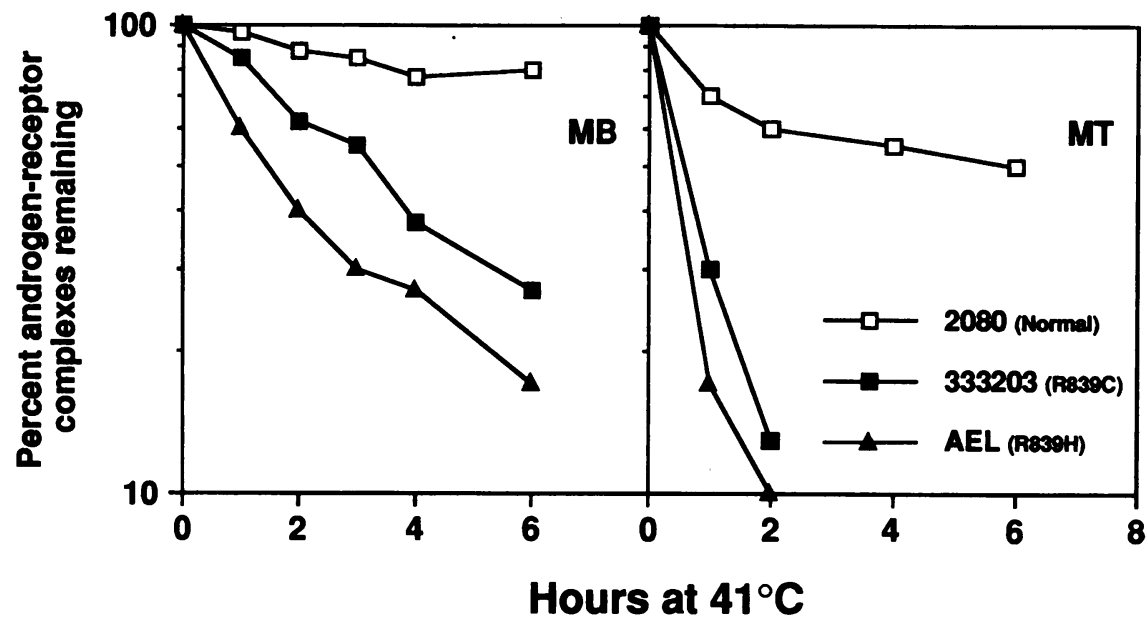

Figure 5. MB- and MT-R complexes were formed in GSF incubated with $3 \mathrm{nM}\left[{ }^{3} \mathrm{H}\right] \mathrm{MB}$ or $\mathrm{MT}$ at $37^{\circ} \mathrm{C}$ ( 0 time $)$. The cells were then postincubated at $41^{\circ} \mathrm{C}$ with $100 \mu \mathrm{M}$ cycloheximide and $3 \mathrm{nM}$ of the same $\left[{ }^{3} \mathrm{H}\right]$ androgen. A-R complexes remaining were measured at intervals up to $6 \mathrm{~h}$. 2080, normal; 333202, Arg839Cys; A.E.L., Arg839His. 
Table I. Rate Constants of Dissociation $\left(k ; 10^{-3} \mathrm{~min}^{-1}\right)$ of Control and Mutant A-R Complexes in GSF Monolayers at Various Temperatures

\begin{tabular}{|c|c|c|c|c|c|c|c|c|}
\hline & & & & & & & MB & \\
\hline & & & & & & & ${ }^{\circ} \mathrm{C}$ & \\
\hline & 37 & 40 & 42 & 32 & 37 & 37 & 40 & 42 \\
\hline $4308 *$ & $9^{\ddagger}$ & & & & $30^{\ddagger}$ & 4 & & $16^{\ddagger}$ \\
\hline & $8^{\ddagger}$ & & & & 15 & & & $14^{\ddagger}$ \\
\hline A.E.L.* & 10 & 15 & 28 & 8 & 17 & 4 & 15 & 18 \\
\hline & 10 & & & & & 5 & & \\
\hline $335002^{\S}$ & 6 & & 17 & & 12 & 3 & & 15 \\
\hline $333203^{\S}$ & 5 & & & & 16 & 3 & & \\
\hline Control(s) & 6 & 10 & 17 & 6 & 12 & 3 & 6 & 9 \\
\hline$\pm \mathrm{SD}(\mathrm{n})$ & $\pm 1(30)$ & & & & $\pm 2(26)$ & $\pm 0.5(25)$ & & $\pm 0.7(12)$ \\
\hline
\end{tabular}

The monolayers were incubated in serum-free medium at $37^{\circ} \mathrm{C}$ with $3 \mathrm{nM}\left[{ }^{3} \mathrm{M}\right]$ androgen alone or together with $0.6 \mu \mathrm{M}$ radioinert androgen. Specific androgen-binding activity was measured at $1 \mathrm{~h}$, then the cells were washed and chased with the same medium containing only radioinert androgen, and the rate of decline of the activity was measured at intervals for 2 h. $* 4308$ and A.E.L. (unrelated) share Arg839His. ${ }^{\ddagger}$ From Table I in reference $22 . \$ 335002 / 333203$, brothers, share Arg839Cys.

fected ARs. To prove that Arg839His or Cys are pathogenic substitutions, we created each mutation in an otherwise normal hAR cDNA expression vector and transiently transfected it into COS- 1 cells. Table II shows that the cells with the Arg839His $\mathrm{AR}$, but not those with the Arg839Cys AR, had higher $37^{\circ} \mathrm{C} k$ values for all three androgens than those with the normal $A R$. These results conserved the pattern of $37^{\circ} \mathrm{C} k$ values in normal and either type of mutant GSF.

Likewise, the MB-Arg839His receptor complexes produced in COS- 1 cells at $37^{\circ} \mathrm{C}$ were more thermolabile than their Arg839Cys counterparts when shifted to $42.5^{\circ} \mathrm{C}$ (Fig. $6 \mathrm{~A}$ ). In contrast, as previously shown for GSF, when the transfected COS- 1 cells were first exposed to a temperature of $42.5^{\circ} \mathrm{C}$ in the presence of $100 \mu \mathrm{M}$ cycloheximide and then measured for androgen-binding activity at various intervals, there was no appreciable difference between the thermostability of the normal receptor and either of the two mutant ARs (Fig. $6 \mathrm{~B}$ ).

Fig. $7 A$ shows that in COS- 1 cells treated with MB 6-80 h after cotransfection the Arg839His AR had a clear tendency to be less active in promoting transcription of the GH gene than the Arg839Cys AR and that both of them were less active than the normal hAR.

We also assessed stability of the normal and either type of mutant AR in COS- 1 cells by measuring their androgen-binding activities during various intervals after transfection. Fig. 8 shows that the normal binding activity was stable, or relatively so, during prolonged $(46-120 \mathrm{~h})$ incubation at all MB concentrations tested, whereas both types of mutant activities were clearly unstable at the same MB concentrations. Again, the Arg839His mutant was inferior to the Arg839Cys. The approximate $50 \%$ difference between the 2 -h binding activities at the beginning and the end of the prolonged exposure to MB reflects the transience of the transfections. In this respect, all three transfections behaved very similarly.

In another transfection experiment using only $3 \mathrm{nM}$ MB (Fig. 9), the normal and mutant androgen-binding activities were subjected to immunoblot analysis. As above, the 118120 - $\mathrm{h}$ binding activities were $40-50 \%$ of those in their $46-48-$ $\mathrm{h}$ counterparts, and their respective blot intensities were appropriate. As before (Fig. 8), prolonged (46-120 h) incubation with MB caused cells with Arg839His to lose more ( $>75 \%$ ) of their starting binding activity than cells with Arg839Cys $(50 \%)$. Under the same conditions, the cells with the wildtype hAR essentially maintained their initial androgen-binding activity. After prolonged $\mathrm{MB}$ incubation, the immunoreactivities of the wild-type hAR and both mutant forms increased relative to their respective androgen-binding activities. This implies that fractions of their respective pools of ARs were in a

Table II. Ligand-specific $k$ of the Normal and Mutant hARs in GSF and COS-1 Cells at $37^{\circ} \mathrm{C}$

\begin{tabular}{lccccrc}
\hline & \multicolumn{5}{c}{ Dissociation rate $\left(\times 10^{-3} \mathrm{~min}^{-1}\right)$} \\
\cline { 2 - 7 } & \multicolumn{3}{c}{ Normal } & & Arg839Cys & Arg839His \\
\hline Ligand & GSF & COS-1 & GSF* & COS-1 & GSF* & COS-1 \\
MB & $3.0 \pm 0.1^{\ddagger}$ & $3.1 \pm 0.10$ & $3.0 \pm 0.00$ & $3.2 \pm 0.30$ & $4.3 \pm 0.33$ & $4.9 \pm 0.35$ \\
DHT & $6.3 \pm 0.25$ & $7.1 \pm 0.35$ & $5.3 \pm 0.75$ & $6.9 \pm 0.65$ & $9.3 \pm 0.48$ & $9.2 \pm 0.70$ \\
MT & $12 \pm 0.5$ & $12.3 \pm 0.30$ & $14.3 \pm 2.25$ & $10.9 \pm 0.70$ & $20.7 \pm 4.70$ & $15.6 \pm 0.20$
\end{tabular}

* The GSF values have been combined for affected members of the same family or unrelated subjects with the same mutation. ${ }^{\ddagger}$ The values are the mean \pm SE. 


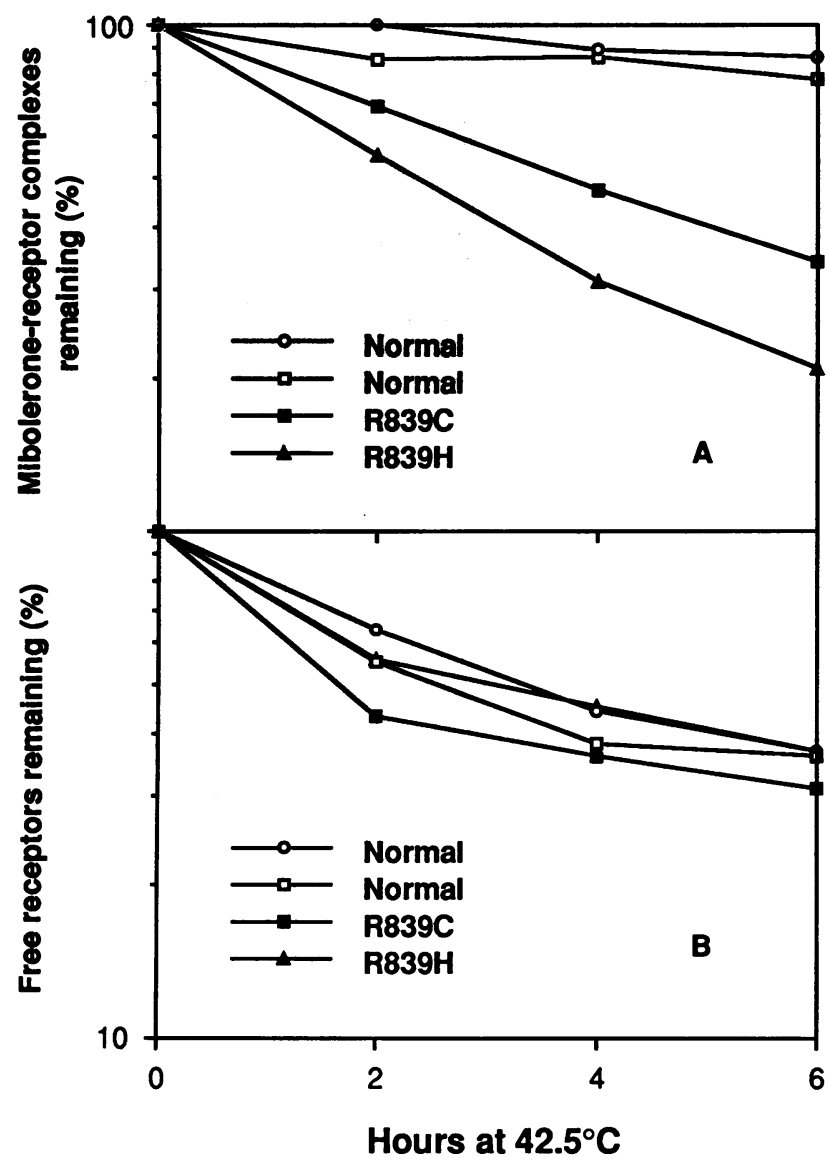

Figure 6. (A) MB-receptor complexes were formed in COS-1 cells incubated with $2.4 \mathrm{nM} \mathrm{MB}$ at $37^{\circ} \mathrm{C}$ for $2 \mathrm{~h}(46-48 \mathrm{~h}$ after transfection; 0 time). The cells were then postincubated at $42.5^{\circ} \mathrm{C}$ under the conditions defined in the legend to Fig. 5, and residual MB-receptor complexes were measured at intervals up to $6 \mathrm{~h}$. $O$, Two samples of normal hAR cDNA expression plasmid transfected separately. (B) $48 \mathrm{~h}$ after transfection, COS- 1 cells at $37^{\circ} \mathrm{C}$ were incubated at $42.5^{\circ} \mathrm{C}$ in the presence of $100 \mu \mathrm{M}$ cycloheximide. Thereafter, at intervals up to $6 \mathrm{~h}$, the decline of mibolerone-binding activity was measured by incubating with $3 \mathrm{nM} \mathrm{MB}$ for $1 \mathrm{~h}$ at $37^{\circ} \mathrm{C}$.

non-androgen-binding state; it is evident that these fractions were greater for the mutants.

In Fig. $7 B$, for each of three experiments, we replotted $\mathrm{GH}$ production (shown in aggregate in Fig. $7 \mathrm{~A}$ ) against relative MB-binding activity during prolonged (6-78 h) MB incubation. In two experiments, the normal and mutant receptors were indistinguishable; in the third, the differences were slight.

\section{Discussion}

In our initial report (28) on the partial androgen insensitivity syndrome in 4308 , we noted that her GSF AR phenotype was distinctive; for instance, her DHT-receptor complexes had questionably increased $37^{\circ} \mathrm{C} k$ values, yet the $42^{\circ} \mathrm{C} k$ values for her $\mathrm{MB}-$ receptor complexes were clearly high. Many years later, we realized that 4308 and the unrelated half-sisters, A.E.L./K.E.L., shared not only the Arg839His AR but also a very similar GSF AR phenotype and predominantly female external genitalia. The broad phenotypic similarity in the two
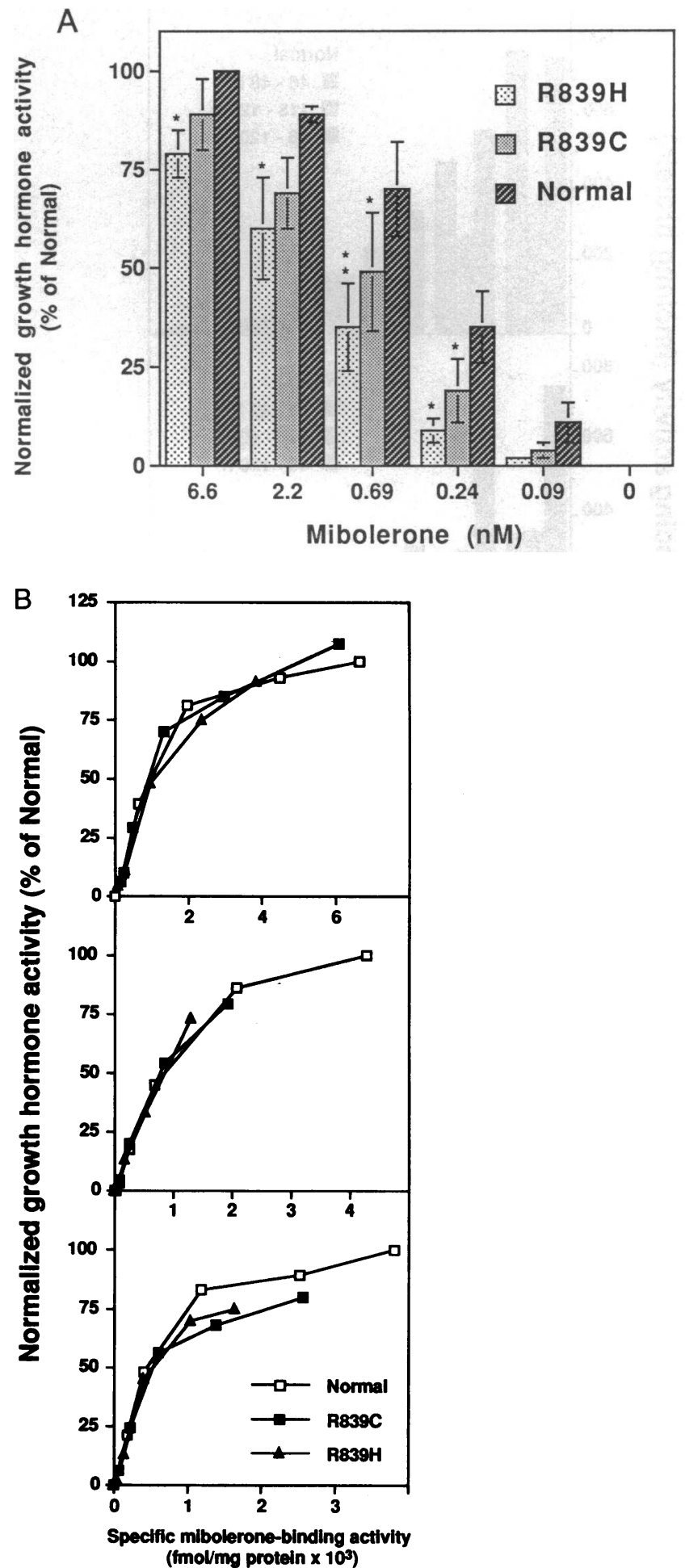

Figure 7. (A) COS-1 cells were transfected with normal hAR expression plasmid, or with a plasmid containing either mutant AR, and also with both the MMTV.GH and CMV. $\beta$-gal plasmids. $6 \mathrm{~h}$ after transfection, different concentrations of MB were added to the medium, and $72 \mathrm{~h}$ later samples of medium and cells were taken to measure $\mathrm{GH}$ and $\beta$-gal activity, respectively. The latter activity was used to assess transfection efficiency, and the GH values were normalized for variation in that efficiency. ${ }^{*} P<0.05$ versus normal; $* * P<0.05$ versus normal or R839C. $(B)$ The GH data above are replotted against specific MBbinding activities at a given concentration of MB in the 6-78-h intervals after transfection. 


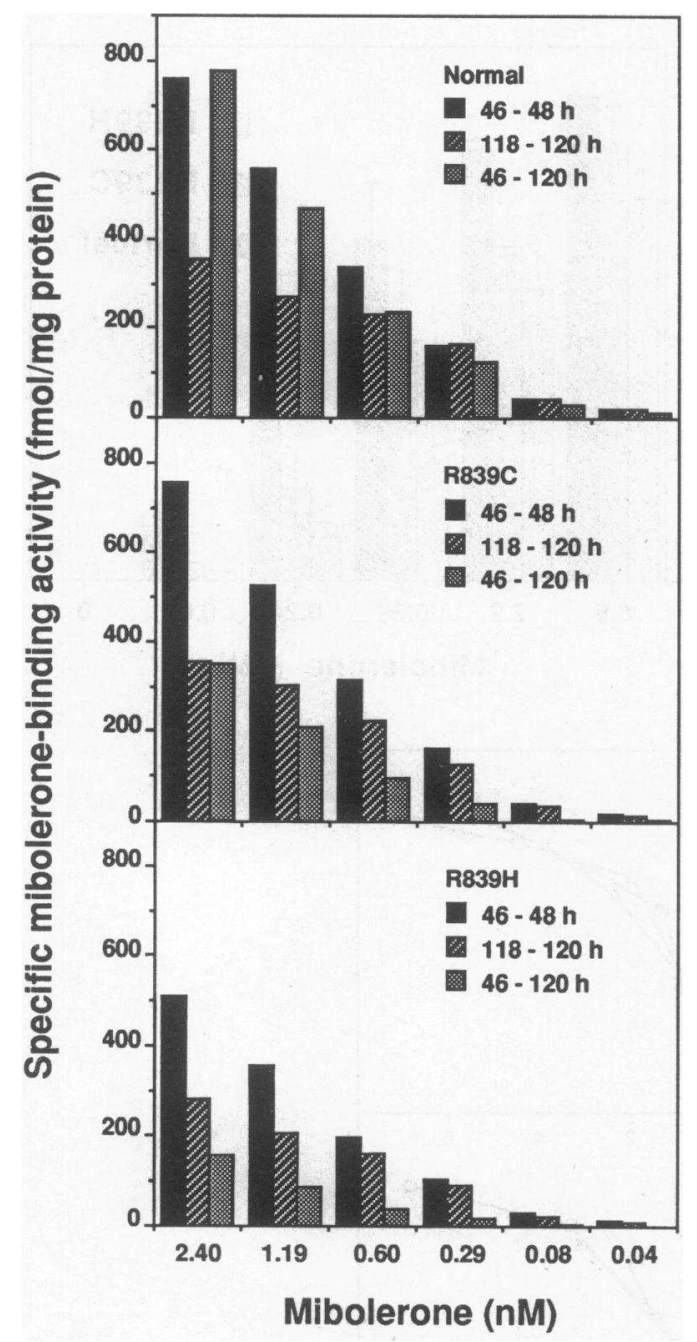

Figure 8. COS-1 cells were transfected with normal hAR expression plasmid or with plasmid containing either mutant AR. Specific MBbinding activity at various concentrations of MB was measured for 2 $\mathrm{h}$, at 46 and $118 \mathrm{~h}$ after transfection, and for $74 \mathrm{~h}$, from 46 to $120 \mathrm{~h}$ after transfection.

families with Arg839His AR appreciated in value both by similarity and by contrast with the Arg839Cys AR in the brothers (335002/333203) with partial androgen insensitivity (AI). For example, in GSF both mutant ARs had variably elevated but overlapping $K_{\mathrm{d}}$ values for all three androgens, and their respective $\mathrm{MB} k$ values were normal at $37^{\circ} \mathrm{C}$ but elevated at $40-42^{\circ} \mathrm{C}$. By contrast, the GSF with Arg839His had slightly to moderately elevated DHT $k$ values at $37-42^{\circ} \mathrm{C}$, while the corresponding values for those with Arg839Cys were normal.

The fact that the GSF with Arg839His had abnormal DHT $k$ values while those with Arg839Cys did not corresponded with the greater undermasculinization of the subjects with Arg839His than those with Arg839Cys. This was borne out by the relative transregulatory dysfunction of each mutant receptor within transfected COS-1 cells: the Arg839His AR was less active than the Arg839Cys AR when GH production was plotted against MB concentration. Importantly, however, the difference disappeared when $\mathrm{GH}$ production was plotted against specific MB-

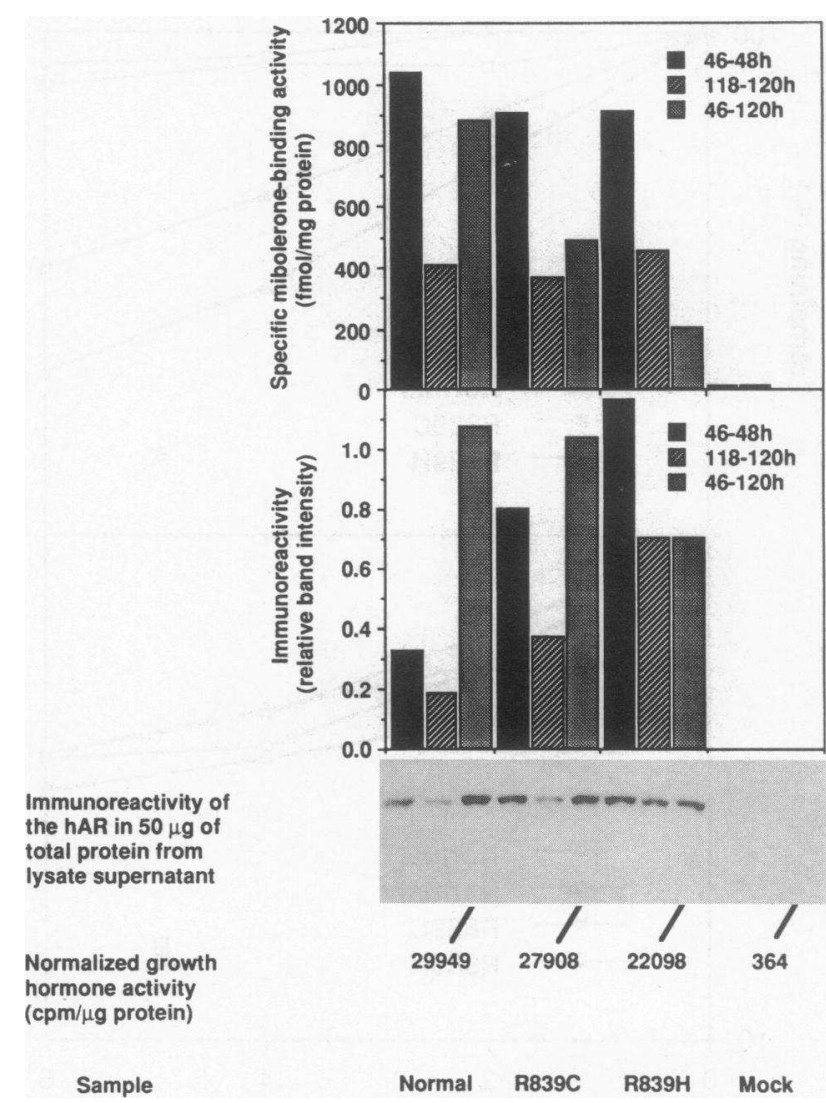

Figure 9. Androgen-binding activity (top, not corrected for transfection efficiency) and immunoreactivity (middle and bottom) were measured concurrently after the addition of $3 \mathrm{nM}$ MB for various intervals to replicate wells of COS-1 cells that had been cotransfected with pMMTV.GH and pCMV. $\beta$-gal alone (Mock) or additionally with pSV.hAR.BHEX (Normal) or one of its two mutant versions, R839H or R839C.

binding activity. This suggested that the mutant MB-receptor complexes had normal intrinsic transactivational competence, but that they were unstable during prolonged exposure to MB. An immunoblot analysis revealed that some of the mutant AR instability reflected conversion of the mutant AR to a nonandrogen-binding state. Such a state may be a part of normal intracellular AR recycling (38), but the mutant ARs may be abnormally disposed to occupy it. Despite these observations, it is important to appreciate that there is strong theoretical and experimental (39) reason to believe that the transregulatory activity of normal or mutant (40) steroid receptors is influenced by cell type and by the promoter context of a particular target gene. Hence, the disparity we observed among the normal and mutant ARs using the MMTV.hGH reporter gene in COS-1 cells might well change in degree and/or quality, if we were to use a reporter gene with a different androgen-responsive promoter context and a transfectant cell type with a different set of cofactors that affect the transregulatory activity (or stability) of the normal and mutant ARs. The ideal candidates would be physiologic target cells rendered AR-free and reporter genes whose products are essential for male sexual differentiation.

Our data and the fact that all the other steroid receptors have lysine in the position homologous to Arg-839 in the AR 
(Fig. 1) imply that the hAR must have Arg or Lys at position 839 to function normally. Our data also suggest that His-839 tends to disrupt the AR more than Cys-839 does: the former is likely to cause predominantly female external genitalia and a female sex-of-rearing; the latter is likely to cause predominantly male external genitalia and a male sex-of-rearing. The two unrelated individuals with Arg839Cys reported by others (25) also had partial AI with a male phenotype (Reifenstein syndrome) and, as we have found, in the GSF of the one tested, MBreceptor complexes had normal $37^{\circ} \mathrm{C} k$ values. Others have found the Arg839His mutation in four unrelated individuals. All four had partial AI: two with a female phenotype $(25,27)$, one with a male phenotype (25), and one ambiguous (41). Importantly, as we found, in the GSF from the one subject with a female phenotype tested, the AR had an increased $k$ value for $\mathrm{MB}$ at $37^{\circ} \mathrm{C}(25)$. Remarkably, the GSF of the one with a male phenotype had almost unmeasurable androgen-binding activity, typical of subjects with complete AI (25). This is a striking indication that "background" factors can mitigate the typical clinical expression of an $A R$ mutation.

The fact that neither the His nor the Cys substitution of Arg-839 disrupts the AR sufficiently to cause complete AI is provocative, in light of information available on the same set of substitutions at two other Arg codons in the AR's androgenbinding domain. For instance, Arg773Cys disrupts the AR phenotype more than Arg773His (12), yet both cause complete AI exclusively $(12,24,26)$, possibly because Arg- $773^{4}$ is within an ultraconserved region of the androgen-binding domain. Contrarily, Arg854Cys has caused complete AI in three out of three subjects $(25,26,42)$, while Arg854His has caused partial AI in three out of four subjects $(24,25,43)$, yet Arg- $854^{5}$ is at the $\mathrm{NH}_{2}$-terminal limit of an 11-amino acid stretch that is absolutely identical among the members of the AR subfamily. The facts that Arg-839 is not within a highly conserved region of the androgen-binding domain and that neither Cys-839 nor His-839 causes complete AI indicate that Arg-839 is less important than Arg-773 or Arg-854 to the AR's androgen-binding properties. It is also noteworthy that Cys-839 appears to be less disruptive than His-839, whereas Cys-773 and Cys-854 appear to be more disruptive than His-773 and His-854, respectively. Perhaps this is because Cys- 839 does not provoke a harmful disulphide bridge, whereas Cys-773 and Cys-854 do. This hypothesis is strengthened by the ligand- and temperature-restricted character of the moderately abnormal nonequilibrium rate constants of dissociation that we have observed in GSF carrying either of the present mutations. In the GSF of most subjects with complete AI due to missense mutations in their androgen-binding domains, these rate constants of dissociation are more abnormal absolutely and seldom ligand- or temperature-restricted (14).

Arg839Cys and Arg839His represent G:C $\rightarrow$ A:T transitions. This reflects the tendency for cytosines at $\mathrm{CpG}$ dinucleotides to become thymines by methylation at carbon 5 and spontaneous deamination at carbon 4 . Indeed, 9 out of 28 point mutations

4. Number according to reference 4: the same codon is numbered 774 in reference 24 and 772 in reference 25 .

5. Number according to reference 4 : the same codon is numbered 855 in reference 24 and 853 in reference 25 . that we have identified in the $h A R$ gene fall into this category (14).

\section{Acknowledgments}

We are grateful to Rhona Rosenzweig and Sandy Fraiberg for faithful secretarial assistance.

This work was supported by the Medical Research Council of Canada and the Fonds de la Recherche en Santé du Québec.

\section{References}

1. Keenan, B. S., W. J. Meyer III, A. J. Hadjian, H. W. Jones, and C. J. Migeon. 1974. Syndrome of androgen insensitivity in man: absence of $5 \alpha$-dihydrotestosterone binding protein in skin fibroblasts. J. Clin. Endocrinol. \& Metab. 38:1143-1146.

2. Kaufman, M., C. Straisfeld, and L. Pinsky. 1976. Male psuedohermaphroitism presumably due to target organ unresponsiveness to androgens. Deficien $5 \alpha$-dihydrotestosterone binding in cultured skin fibroblasts. J. Clin. Invest. 58:345-350.

3. Griffin, J. E., K. Punyashthiti, and J. D. Wilson. 1976. Dihydrotestosterone binding by cultured human fibroblasts. Comparison of cells from control subjects and from patients with hereditary male pseudohermaphroditism due to androgen resistance. J. Clin. Invest. 57:1342-1351.

4. Chang, C., J. Kokontis, and S. Liao. 1988. Structural analysis of complementary DNA and amino acid sequences of human and rat androgen receptors. Proc. Natl. Acad. Sci. USA. 85:7211-7215.

5. Lubahn, D. B., D. R. Joseph, M. Sar, J. Tan, H. N. Higgs, R. E. Larson, F. S. French, and E. M. Wilson. 1988. The human androgen receptor: complementary deoxyribonucleic acid cloning, sequence analysis and gene expression in protstate. Mol. Endocrinol. 2:1265-1275.

6. Trapman, J., P. Klaassen, G. G. J. M. Kuiper, J. A. G. M. van der Korput, P. W. Faber, H. C. J. van Rooij, A. Guerts van Kessel, M. M. Voorhorst, E. Mulder, and A. O. Brinkmann. 1988. Cloning, structure and expression of a cDNA encoding the human androgen receptor. Biochem. Biophys. Res. Commun. 153:241-248.

7. Tilley, W. D., M. Marcelli, J. D. Wilson, and M. J. McPhaul. 1989. Characterization and expression of a cDNA encoding the human androgen receptor Proc. Natl. Acad. Sci. USA. 86:327-331.

8. Sai, T., S. Seino, C. Chang, M. Trifiro, L. Pinsky, A. Mhatre, M. Kaufman, B. Lambert, J. Trapman, A. O. Brinkmann, et al. 1990. An exonic point mutation of the androgen receptor gene in a family with complete androgen insensitivity Am. J. Hum. Genet. 46:1095-1100.

9. Ris-Stalpers, C., M. A. Trifiro, G. G. J. M. Kuiper, G. Jenster, G. Romalo, T. Sai, H. C. J. van Rooij, M. Kaufman, R. L. Rosenfield, S. Liao, et al. 1991 Substitution of aspartic acid 686 by histidine or asparagine in the human androgen receptor leads to a functionally inactive protein with altered hormone-binding characteristics. Mol. Endocrinol. 5:1562-1569.

10. Trifiro, M., B. Gottlieb, L. Pinsky, M. Kaufman, L. Prior, D. D. Belsham, K. Wrogemann, C. J. Brown, H. F. Willard, J. Trapman, et al. 1991. The 56/58 $\mathrm{kDa}$ androgen-binding protein in male genital skin fibroblasts with a deleted androgen receptor gene. Mol. Cell. Endocrinol. 75:37-47.

11. Trifiro, M., R. L. Prior, N. Sabbaghian, L. Pinsky, M. Kaufman, E. G. Nylen, D. D. Belsham, C. R. Greenberg, and K. Wrogemann. 1991. Amber mutation creates a diagnostic MaeI site in the androgen receptor gene of a family with complete androgen insensitivity. Am. J. Med. Genet. 40:493-499.

12. Prior, L., S. Bordet, M. A. Trifiro, A. Mhatre, M. Kaufman, L. Pinsky, K. Wrogemann, D. D. Belsham, F. Periera, C. Greenberg, et al. 1992. Replacement of arginine 773 by cysteine or histidine in the human androgen receptor causes complete androgen insensitivity with different receptor phenotypes. Am. J. Hum. Genet. 51:143-155.

13. Kazemi-Esfarjani, P., L. K. Beitel, M. Trifiro, M. Kaufman, P. Rennie, P. Sheppard, R. Matusik, and L. Pinsky. 1993. Substitution of valine- 865 by methionine or leucine in the human androgen receptor causes complete or partial androgen insensitivity, respectively with distinct androgen receptor phenotypes. $\mathrm{Mol}$. Endocrinol. 7:37-46.

14. Pinsky, L., M. Trifiro, M. Kaufman, L. K. Beitel, A. Mhatre, P. KazemiEsfarjani, N. Sabbaghian, R. Lumbroso, C. Alvarado, M. Vasiliou, and B. Gottlieb. 1992. Androgen resistance due to mutation of the androgen receptor. Clin. Invest. Med. 15:456-472.

15. Brown, T. R., D. B. Lubahn, E. M. Wilson, D. R. Joseph, F. S. French, and C. J. Migeon. 1988. Deletion of the steroid-binding domain of the human androgen receptor gene in one family with complete androgen insensitivity syndrome: evidence for further genetic heteogeneity in this syndrome. Proc. Natl. Acad. Sci. USA. 85:8151-8155. 
16. Brown, T. R., D. B. Lubahn, E. M. Wilson, F. S. French, C. J. Migeon, and J. L. Corden. 1990. Functional characterization of naturally occurring mutant androgen receptors from subjects with complete androgen insensitivity. Mol. Endocrinol. 4:1759-1772.

17. Ris-Stalpers, C., G. G. J. M. Kuiper, P. W. Faber, H. U. Scherikert, H. C. J. van Rooji, N. D. Zegers, M. B. Hodgins, H. J. Degenhart, J. Trapman, and A. O. Brinkmann. 1990. Aberrant splicing of androgen receptor mRNA results in synthesis of a nonfunctional receptor protein in a patient with androgen insensitivity. Proc. Natl. Acad. Sci. USA. 87:7866-7870.

18. Akin, J. W., A. Behzadian, S. P. T. Tho, and P. G. McDonough. 1991. Evidence for a partial deletion in the androgen receptor gene in a phenotypic male with azoospermia. Am. J. Obstet. Gynecol. 165:1891-1894.

19. Marcelli, M., W. D. Tilley, C. M. Wilson, J. D. Wilson, J. E. Griffin, and M. J. McPhaul. 1990. A single nucleotide substitution introduces a premature termination codon into the androgen receptor gene of a patient with receptornegative androgen resistance. J. Clin. Invest. 85:1522-1528.

20. Marcelli, M., W. D. Tilley, S. Zoppi, J. E. Griffin, J. D. Wilson, and M. J. McPhaul. 1991. Androgen resistance associated with a mutation of the androgen receptor at amino acid 772 (Arg $\rightarrow$ Cys) results from a combination of decreased messenger ribonucleic acid levels and impairment of receptor function. J. Clin. Endocrinol. \& Metab. 73:318-325.

21. McPhaul, M. J., M. Marcelli, W. D. Tilley, J. E. Griffin, R. F. IsidroGutierrez, and J. D. Wilson. 1991. Molecular basis of androgen resistance in a family with a qualitative abnormality of the androgen receptor and responsive to high-dose androgen therapy. J. Clin. Invest. 87:1413-1421.

22. Nakao, R., M. Haji, T. Yanase, A. Ogo, R. Takayanagi, T. Katsube, Y. Fukumaki, and H. Nawata. 1992. A single amino acid substitution (Met ${ }^{786} \rightarrow$ $\mathrm{Val}$ ) in the steroid-binding domain of human androgen receptor leads to complete androgen insensitivity syndrome. J. Clin. Endocrinol. \& Metab. 74:1152-1157.

23. Jakubiczka, S., E. A. Werder, and P. Wieacker. 1992. Point mutation in the steroid-binding domain of the androgen receptor gene in a family with complete androgen insensitivity syndrome (CAIS). Hum. Genet. 90:311-312.

24. Batch, J. A., D. M. Williams, H. R. Davies, B. D. Brown, B. A. J. Evans, I. A. Hughes, and M. N. Patterson. 1992. Androgen receptor gene mutations identified by SSCP in fourteen subjects with androgen insensitivity syndrome. Hum. Mol. Genet. 1:497-503.

25. McPhaul, M. J., M. Marcelli, S. Zoppi, C. M. Wilson, J. E. Griffin, and J. D. Wilson. 1992. Mutations in the ligand-binding domain of the androgen receptor gene cluster in two regions of the gene. J. Clin. Invest. 90:2097-2101.

26. De Bellis, A., C. A. Quigley, N. F. Cariello, M. K. El-Awady, M. Sar, M. V. Lane, E. M. Wilson, and F. S. French. 1992. Single base mutations in the human androgen receptor gene causing complete androgen insensitivity: rapid detection by a modified denaturing gradient gel electrophoresis technique. Mol. Endocrinol. 6:1909-1920.

27. Hiort, O., Q. Huang, G. H. G. Sinnecker, A. B. Sadeghi-Nejad, K. Kruse, H. J. Wolfe, and D. W. Yandell. 1993. Single strand conformation polymorphism analysis of androgen receptor gene mutations in patients with androgen insensitivity syndromes: application for diagnosis, genetic counseling, and therapy. J. Clin. Endocrinol. \& Metab. 77:262-266.

28. Pinsky, L., M. Kaufman, and L. L. Levitsky. 1987. Partial androgen resistance due to a distinctive qualitative defect of the androgen receptor. Am. J. Med. Genet. 27:459-466.

29. Gottlieb, B., M. Kaufman, L. Pinsky, G. Leboeuf, and J. F. Sotos. 1987.
Extracellular correction of the androgen-receptor transformation defect in two families with complete androgen resistance. J. Steroid Biochem. 28:279-284.

30. Beitel, L. K., L. Prior, D. M. Vasiliou, B. Gottlieb, M. Kaufman, R. Lumbroso, C. Alvarado, B. McGillivray, M. Trifiro, and L. Pinsky. 1993. Complete androgen insensitivity due to mutations in the probable $\alpha$-helical segments of the DNA-binding domain in the human androgen receptor. Hum. Mol. Genet. 3:21-27.

31. Higuchi, R. 1990. Recombinant PCR. In PCR Protocols: A Guide to Methods and Applications. M. A. Innis, D. H. Gelfand, J. J. Sninsky, and T. J. White, editors. Academic Press Inc., San Diego. 277-283.

32. Brinkmann, A. O., P. W. Faber, H. C. J. van Rooij, G. G. J. M. Kuiper, C. Ris, P. Klaassen, J. A. G. M. van der Korput, M. M. Voorhorst, J. H. van Laar, E. Mulder, and J. Trapman. 1989. The human androgen receptor: domain structure, genomic organization and regulation of expression. J. Steroid Biochem. 34:307-310.

33. Lowry, O. H., N. J. Rosebrough, A. L. Farr, and R. J. Randall. 1951 Protein measurement with the Folin phenol reagent. J. Biol. Chem. 193:265-275.

34. Sambrook, J., E. F. Fritsch, and T. Maniatis. 1989. Molecular Cloning. 2nd ed. Cold Spring Harbor Laboratory, Cold Spring Harbor, NY. 18.3-18.74.

35. Zegers, N. D., E. Claassen, C. Neelan, E. Mulder, J. H. van Laar, M. M. Voorhorst, C. A. Berrevoets, A. O. Brinkmann, T. H. van der Kwast, J. A Ruizeveld de Winter, et al. 1991. Epitope prediction and confirmation for the human androgen receptor: generation of monoclonal antibodies for multi-assay performance following the synthetic peptide strategy. Biochim. Biophys. Acta. 1073:23-32.

36. Edwards, A., H. A. Hammond, L. Jin, C. T. Caskey, and R. Chakraborty. 1992. Genetic variation at five trimeric and tetrameric tandem repeat loci in four human population groups. Genomics 12:241-253.

37. Kaufman, M., L. Pinsky, B. Gottlieb, M. Schweitzer, A. Brezezinski, C. von Westarp, and J. Ginsberg. 1990. Androgen receptor defects in patients with minimal and partial androgen resistance classified according to a model of androgen-receptor complex energy states. Horm. Res. (Basel). 33:87-94.

38. Rossini, G. P., and S. Liao. 1982. Intracellular inactivation, reactivation, and dynamic status of prostate androgen receptors. Biochem. J. 208:383-392.

39. Adler, A. J., A. Scheller, and D. M. Robins. 1993. The stringency and magnitude of androgen-specific gene activation are combinatorial functions of receptor and nonreceptor binding site sequences. Mol. Cell. Biol. 13:6326-6335.

40. Tzukerman, M. T., A. Esty, D. Santiso-Mere, P. Danielian, M. G. Parker, R. B. Stein, J. W. Pike, and D. P. McDonnell. 1994. Human estrogen receptor transactivational capacity is determined by both cellular and promoter context and mediated by two functionally distinct intramolecular regions. Mol. Endocrinol. 8:21-30.

41. De Bellis, A., C. A. Quigley, K. B. Marschke, M. K. El-Awady, M. V. Lane, E. P. Smith, M. Sar, E. M. Wilson, and F. S. French. 1994. Characterization of mutant androgen receptors causing partial androgen insensitivity syndrome. $J$. Clin. Endocrinol. \& Metab. 78:513-522.

42. Tincello, D. G., T. B. Hargreave, F. C. Wu, T. Padayachi, and P. T. Saunders. 1992. Mutations in the androgen receptor gene of patients with androgen insensitivity. J. Endocrinol. 132(Suppl.):87. (Abstr.)

43. Chang, Y. T., C. J. Migeon, and T. R. Brown. 1991. Human androgen insensitivity syndrome due to androgen receptor gene point mutations in subjects with normal androgen receptor levels but impaired biological activity. 73rd Annual Meeting of the Endocrine Society. 37:28. (Abstr.) 